\title{
Membangun Website Sistem Informasi Dinas Pariwisata
}

\author{
Hj. Nurmi \\ Dosen Pendidikan Informatika STKIP PGRI Sumbar \\ olmiinu@yahoo.com
}

\begin{abstract}
ABSTRAK
Perancangan dan penerapan sistem informasi objek pariwisata berbasis web sangat membantu dalam pemilihan objek-objek pariwisata dan mempermudah para wisatawan dalam memperoleh informasi yang lebih lengkap dan efisien. Metodologi yang digunakan dalam perancangan ini menggunakan teknik pengumpulan data dengan melakukan pengumpulan data melalui observasi, wawancara dan kuesioner. Penelitian Perpustakaan (Library Research), laboratorium dan Konsep SDLC (System Development Lyfe Sycle) dengan tahapan perencanaan (Initiation and Planning), analisis (Analysis), perancangan secara logika (Logical Design), perancangan secara fisik (Physical Design), imlpementasi (Implementation) dan pemeliharaan (Maintenance).Sistem informasi website objek pariwisata dapat mengatasi beberapa hambatan diantaranya : (a) sistem dapat mengatasi kesulitan dalam mencari informasi tentang objek wisata, penginapan dan makanan khas yang ada di kota maupun kabupaten, (b) mengatasi kesulitan dalam pencarian data objek wisata secara keseluhan karena sudah mempunyai database, (c) mengatasi dalam pengolahan data dan pembuatan laporan, mendeteksi kesalahan dalam pencatatan dan pembuatan laporan, (d), mengatasi keterlambatan dalam pemberian laporan kepada pihak terkait. Aplikasi ini membantu manajemen dalam pengelolaan dan pengolahan data, sehingga pada dinas pariwisata terjadi peningkatan pelayan, efesiensi, lebih ekonomi, peningkatan pengontrolan dan kualitas informasi lebih terjamin karena menghasilkan informasi yang berkualitas dan bernilai serta bermanfaat. Website Sistem Informasi Dinas Pariwisata, memberi kemudahan kepada wisatawan dalam mengakses informasi objek-objek wisata kota maupun kabupaten dimanapun mereka berada.
\end{abstract}

Kata Kunci : Sistem informasi, objek wisata, website, pengolahan data

\section{PENDAHULUAN}

Sistem informasi adalah suatu aplikasi yang tersusun secara prosedur, terorganisir dan sistematis, pada saat dijalankan akan menghasilkan suatu informasi yang berguna dan bermanfaat bagi organisasi dalam mengelola organisasi untuk mencapai tujuan organisasi. Sistem informasi merupakan salah satu alat bantu yang berguna bagi manajemen untuk mengolah data organisasi dengan kapasitas yang cukup besar. Keunggulan dari sistem informasi ini adalah kecepatan dan ketepatan dalam pengolahan data dengan kapasitas yang cukup besar, dan kemudahan serta kecepatan dalam pencarian data pada tumpukan data yang cukup besar. Dari keunggulan dan kemudahan serta kecepatan dalam pengolahan data maka sistem informasi ini sangat bermanfaat bagi semua instansi baik instansi swasta maupun instansi negeri.

Menurut Undang Undang No. 10/2009 tentang Kepariwisataan, yang dimaksud dengan pariwisata adalah berbagai macam kegiatan wisata yang didukung oleh berbagai fasilitas serta layanan yang disediakan masyarakat, pengusaha, pemerintah dan pemerintah daerah. Dinas Pariwisata merupakan salah satu dinas yang mengelola 
objek wisata di kota/kabupaten. Untuk menunjang perkembangan pariwisata di kota/kabupaten agar dapat dipromosikan ke luar dan dalam negeri terutama di Indonesia digunakan teknologi informasi sebagai penyimpanan data dan penyajian informasi pariwisata secara elektronik, sehingga sistem ini memberikan kemudahan dalam mengakses informasi pariwisata di kota/kabupaten. Diharapkan sistem ini dapat meningkatkan jumlah pengunjung ke objek wisata kota/kabupaten dan pengelolaan serta penataan pariwisata lebih baik.

Sistem informasi objek pariwisata berbasis web sangat membantu dalam pemilihan objek-objek pariwisata dan mempermudah para wisatawan dalam memperoleh informasi yang lebih lengkap dan efisien. Pengolahan data objek pariwisata secara manual, menimbulkan beberapa hambatan antara lain: kesulitan dalam mencari informasi tentang objek wisata, penginapan dan makanan khas yang ada di kota maupun kabupaten, kesulitan dalam mendapatkan data secara keseluruhan atau tidak tergabung dalam suatu database, sehingga tampilan dari data tersebut rumit dan tidak efisien. Berdasarkan permasalahan tersebut perlu dibangun suatu sistem yang dapat memudahkan dalam pengelolaan data objek wisata. Tujuan dibangun sistem ini adalah memberi kemudahan kepada wisatawan dalam mengakses informasi objek-objek wisata kota maupun kabupaten dimanapun mereka berada.

Untuk mengatasi permasalahan dalam pengelolaan dan menata data objek wisata di kota/kabupaten maka perlu dibangun sistem inforamsi Website Dinas Pariwisata.

\section{Identifikasi Masalah}

Berdasarkan latar belakang, maka dapat diidentifikasi masalah sebagai berikut:

1. Sistem manual menyulitkan dalam mencari data/informasi objek wisata dan penginapan yang ada di kota dan kabupaten.
2. Sistem manual, menghasilkan data kurang akurat dan sistem kurang efektif, karena dokumen dan objek wisata belum terkelola dengan baik.

3. Sistem pengolahan data objek wisata di kota/kabupaten pada umumnya belum memiliki database, sehingga sering menimbulkan redudansi data.

\subsection{Pengertian Sistem Informasi}

Menurut John F.Nash dan Martil B.Robert (2006:35) yang diterjemahkan oleh Jugianto H.M, menyatakan bahwa "Sistem Informasi adalah kombinasi dari orang-orang, fasilitas, teknologi, media, prosedur-prosedur dan pengendalian yang ditujukan untuk mendapatkan jalur komunikasi pentingm, memproses tipe transaksi rutin tertentu, memberi sinyal kepada manajemen yang lainnya terhadap kejadian-kejadian internal"

Defenisi sistem informasi pada :

Andre Wijaksono, "Pengertian Sistem Informasi", http://media.kompasiana.com, diakses tanggal 15 Januari 2013, Sistem informasi yaitu suatu sistem yang menyediakan informasi untuk manajemen dalam mengambil keputusan dan juga untuk menjalankan operasional perusahaan, di mana sistem tersebut merupakan kombinasi dari orang-orang, teknologi informasi dan prosedur-prosedur yang tergorganisasi.

\subsection{Web Sistem Informasi Objek Wisata}

Rahmat Hidayat (2010), Website atau sistus dapat diartikan sebagai kumpulan halaman-halaman yang digunakan untuk menampilkan informasi teks, gambar diam atau gerak, animasi, suara dan atau gabungan dari semuanya, baik brsifat statis maupun dinamis yang membentuk suatu rangkaian bangunan yang saling terkait, yang masingmasing dihubungkan dengan jaring-jaringan halaman. Membangun Web Sistem Informasi objek wisata merupakan suatu aplikasi yang dirancang untuk mengolah data objek wisata, dapat diakses secara langsung oleh pengunjung wisata. Sistem ini bertujuan 
untuk menghasilkan informasi tentang tujuan wisata, objek wisata yang menarik, sarana yang tersedia seperti transportasi untuk mencapai tujuan wisata, produk wisata yang diminati dan lain sebagainya. Sistem ini memberikan kemudahan kepada wisatawan tentang pariwisata dan dapat membantu dalam pnyebaran informasi secara luas tanpa mengenal batas waktu dan ruang.

Web sistem informasi dinas pariwisata sangat mendukung dalam pengembangan fungsi pariwisata di kota/kabupaten. Fungsi pengembangan pariwisata antara lain adalah: (1) Pengembangan objek dan daya tarik wisata (2) Meningkatkan dan mengembangkan promosi dan pemasaran (3) Meningkatkan pendidikan dan pelatihan kepariwisataan

\subsection{Jenis Objek Wisata}

\section{Wisata Budaya}

Wisata Budaya merupakan perjalanan yang dilakukan oleh wisatawan untuk kunjungan atau peninjauan ke daerah tertentu guna mempelajari keadaan rakyat, kebiasaan dan adat istiadat rakyat tersebut

\section{Wisata Alam}

Wisata Alam merupakan kunjungan wisatawan ke tempat sehari-hari di mana ia tinggal demi kepentingan beristirahat untuk kesegaran jasmani dan rohani, atau kesuatu tempat yang mengandung mineral yang dapat menyembuhkan, tempat yang mempunyai iklim udara menyehatkan atau tempat-tempat yang menyediakan fasilitasfasilitas kesehatan lainnya.

\section{Wisata Makanan}

Wisata Makanan merupakan wisatawan mengunjungi berbagai macam makanan khas daerah yang merupakan makanan spesifik pada daerah tersebut.

\subsection{Konsep Website}

Website atau situs juga dapat diartikan sebagai kumpulan halaman yang menampilkan informasi data teks, data gambar diam atau gerak, data animasi, suara, video dan atau gabungan dari semuanya, baik yang bersifat statis maupun dinamis yang membentuk satu rangkaian bangunan yang saling terkait dimana masing-masing dihubungkan dengan jaringan-jaringan halaman (hyperlink).

Bersifat statis apabila isi informasi website tetap, jarang berubah, dan isi informasinya searah hanya dari pemilik website. Bersifat dinamis apabila isi informasi website selalu berubah-ubah, dan isi informasinya interaktif dua arah berasal dari pemilik serta pengguna website.

\section{Konsep Membangun Web Sistem Informasi Dinas Pariwisata}

\subsection{Konsep SDLC (System Development Lyfe Sycle) \\ SDLC adalah sebuah siklus hidup} pengembangan perangkat lunak yang terdiri dari :

a. Perencanaan (Initiation and Planning) Membuat dan menetukan tujuan serta sasaran yang akan dihasilkan oleh web sistem informasi pengolahan data objek wisata pada dinas kota/ kabupaten

b. Analisis (Analysis),

Menganalisa sistem yang ada atau yang lama dan menggantikannya dengan sistem yang baru.

c. Perancangan secara Logika (Logical Design)

Membuat beberapa alternatif rancangan terbaik tentang web sistem informasi kemudian memilih salah satu alternatif terbaik untuk dikembangkan dalam menjawab kebutuhan dinas pariwisata kota/kabupaten.

d. Perancangan secara fisik (Physical Design)

Yaitu menentukan bahasa pemograman, database, struktur data sistem operasi,

3 Diterbitkan Oleh Program Studi Pendidikan Informatika STKIP PGRI Sumbar 
jaringan dan spesifikasi perangkat keras dalam membangun web sistem informasi dinas pariwisata.

e. Imlpementasi (Implementation)

Sistem informasi yang dirancang, dibuatkan bahasa pemrograman dengan menggunakan PHP, HTML dan MySql untuk merancang database, kemudian diuji dan diinstall, dan diuji coba dengan dinas pariwisata sebelum digunakan pada dinas tersebut.

f. Pemeliharaan (Maintenance)

Merupakan tahap akhir, dari tahap pembuatan sistem informasi, tahap ini merupakan sistem sudah dapat dioperasikan oleh dinas pariwisata dan dapat dirawat sistem tersebut sampai kepada pengembangan sistem pada priode berikutnya.

\section{HASIL PENELITIAN}

\subsection{Hasil Analisis}

Berdasarkan permasalahan dan kendalakendala yang terjadi pada sistem yang sedang berjalan ini, maka didapatkan beberapa hasil analisis sebagai berikut.

1. Perlu dibanun pengembangan Sistem Informasi Objek Wisata Pada Dinas Pariwisata Payakumbuh Berbasis Web. Website ini berfungsi untuk : memperoleh informasi objek pariwisata dengan cepat dan mudah dan cepat.

2. Sistem dibangun dengan program aplikasi web yang lebih dinamis sehingga mampu menampilkan halaman web lebih sempurna sehingga memudahkan pemakai dalam pencarian informasi.

3. Membentuk suatu media yang dapat menampilkan seluruh objek wisata dan cara pemesanan serta beberapa pilihan objek wisata yang ditawarkan.
4. Pemilihan objek wisata dan pemesanan oleh pengunjung dapat dilakukan melalui website tanpa harus mendatangi Dinas Pariwisata secara langsung.

Hasil analisis ini dapat digambarkan dengan beberapa model alat analisi dan perancangan sistem informasi yaitu :

1. Aliran Sistem Informasi Yang

Diusulkan (ASI Baru) sebagai berikut :

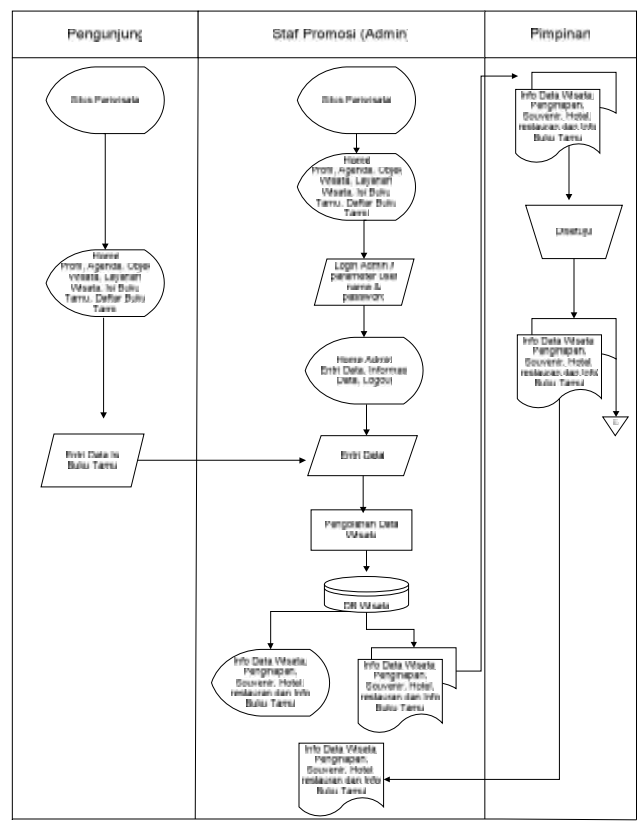

Gambar 1. ASI Baru : Membangun

Website Sistem Informasi Dinas Pariwisata

Dari halaman homepage pengunjung dapat melakukan pencarian informasi berdasarkan kriteria yang disajikan homepage. Homepage pariwisata ini juga menyediakan halaman pemesanan dan buku tamu dan komentar oleh pengunjung sebagai masukan bagi Dinas Pariwisata kota/kabupaten. Data tersebut kemudian disimpan pada database web server dan ditampilkan pada halaman web yang telah diupdate.

Pada halaman homepage administrator membuka halaman web untuk melakukan login dengan memasukkan 
Penelitian Bidang Komputer Sains dan Pendidikan Informatika

V1.i2(1-6)

username dan password yang hanya dimiliki oleh administrator. Browser mengirim parameter login dan password kepada webserver yang akan langsung di cek pada database web server. Setelah proses login disetujui, administrator akan dapat mengelola data pariwisata dinas serta manipulasi data base pariwisata, sehingga informasi tentang pariwisata pada dinas selalu menghasilkan informasi yang terbaru bagi pengunjung pariwisata di lingkungan dinas pariwisata kota/kabupaten.

\subsection{Perancangan Web Sistem Informasi Dinas Pariwisata}

Membangun web Sistem Informasi Dinas Pariwisata dapat digambarkan melalui alat analis dan perancangan sistem berupa Hyrarchy Plus Input Process Output (HIPO). HIPO digunakan sebagai alat desain dan teknik dokumentasi dalam siklus pengembangan sistem, berbasis pada fungsi yaitu tiap-tiap modul didalam sistem digambarkan oleh fungsi utamanya. HIPO Web Sistem Informasi Dinas Pariwisata kota/kabupaten dapat digambarkan sebagai berikut :

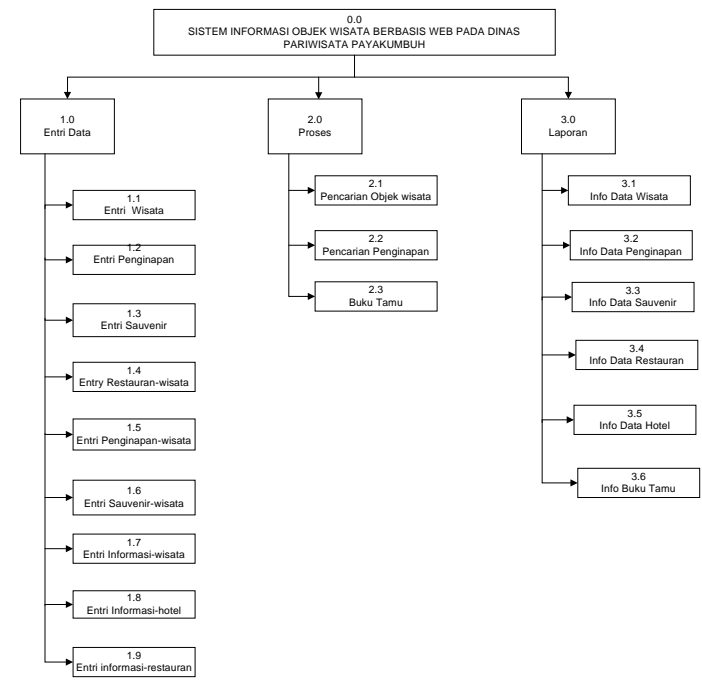

\section{Gambar 2. HIPO Web Sistem Informasi Dinas Pariwisata}

\section{Kesimpulan}

1. Web Sistem informasi objek pariwisata sangat membantu dalam pemilihan objekobjek pariwisata dan mempermudah para wisatawan dalam memperoleh informasi yang lebih lengkap dan efisien.

2. Web Sistem informasi objek pariwisata memberikan kemudahan antara lain: (a) memudahkan dalam mencari informasi tentang objek wisata, penginapan dan makanan khas yang ada di kota maupun kabupaten Payakumbuh, (b) mempercepat dalam pencarian data objek wisata secara keseluhan karena sudah mempunyai database, (c) memudahkan dalam pengelolaan data pariwisata pada dinas pariwisata kota/kabupaten, (d), memberikan informasi dengan tepat, akurat dan berkualitas kepada wisatawan dan kepada pihak terkait.

3. Web Sistem ini membantu manajemen dalam pengelolaan dan pengolahan data, dapat peningkatan pelayan, efesiensi, lebih ekonomi, pengontrolan yang lebih baik dan memberikan nilai manfaat bagi wisatawan dan dinas terkait.

\section{DAFTAR PUSTAKA}

Andre Wijaksono, "Pengertian Sistem Informasi”, http://media.kompasiana.com, diakses tanggal 15 Januari 2013,

Bambang Wahyudi, (2008), Konsep Basis Data, PT Bumi Aksara, Jakarta

Dian Puspita, bahan-ajar, http://dianpuspita.dosen.narotama.ac.i d, diakses tanggal 15 Januari 2013

Febrianai, Aliran Sistem Informasi, http://staff.gunadarma.ac.id, diakses tanggal 23 Januari 2013

Hanif Al Fatta, (2007), Analisis dan Perancangan Sistem Informasi, Andi Offset, Yogyakarta

Hirin A.M dan Virgi, (2011), Cepat Mahir Pemograman Web dengan PHP dan MSQL, PT. Prestasi Pustaka, Jakarta

5 Diterbitkan Oleh Program Studi Pendidikan Informatika STKIP PGRI Sumbar 
Hkm Lamania, Simbol-Sombol Flowchart, http://wordpress.com, diakses tanggal 23 Februari 2013

Jogianto HM, (2009), Sistem Teknologi Informasi, Andi, Yogyakarta

Kusrini, (2007), Konsep dan Aplikasi Pendukung Keputusan, Andi Offset, Yogyakarta

Ridwan, Hirarchy Plus Input Process Output, http://visiridwan.wordpress.com, diakses tanggal 23 Februari 2013

_,http://www.modelbasisdata.com, diakses tanggal 09 Desember 2012

_http://www.perancanganbasisdata.com, diakses tanggal 09 desember 2012 